
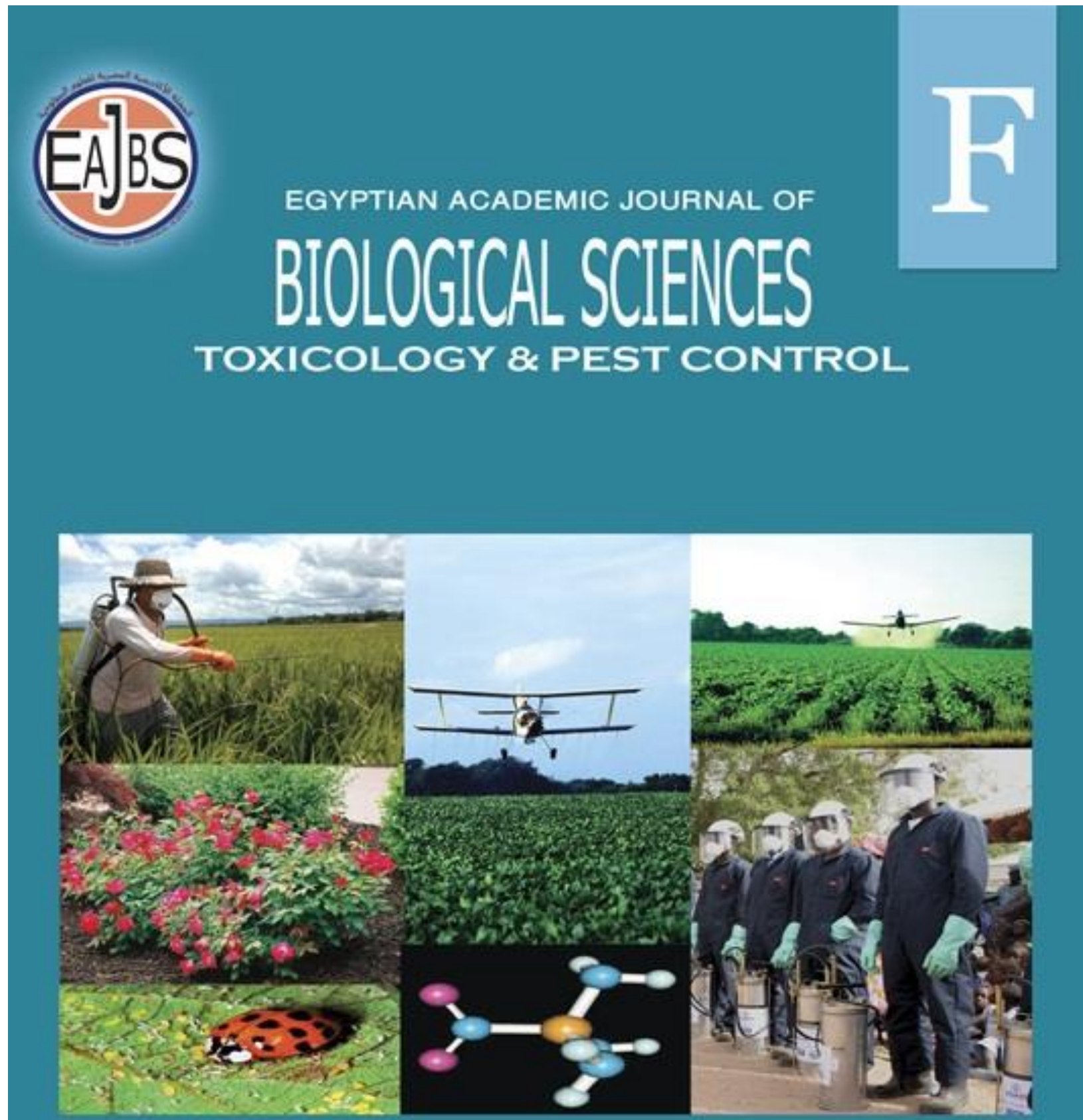

ISSN
$2090-0791$

WWW.EAJBS.EG.NET

Vol. 13 No. 2 (2021)

Citation: Egypt. Acad. J. Biolog. Sci. (F.Toxicology\& Pest control) Vol.13(2)pp155-171(2021) DOI: 10.21608/EAJBSF.2021.204456 
Egypt. Acad. J. Biolog. Sci., 13(2):155-171(2021)

Egyptian Academic Journal of Biological Sciences

F. Toxicology \& Pest Control

ISSN: 2090 - 0791

http://eajbsf.journals.ekb.eg/

\title{
Ameliorative Effect of Jojoba Oil on Monosodium Glutamate Induced Cardiotoxicity and Neurotoxicity: Molecular, Metabolic and Histopathological study
}

\author{
Sahar M. Abo El Wafa ${ }^{1}$, Rania Ebrahim Eldesoky Mohamady ${ }^{2}$ and Sania K. Elwia ${ }^{3 *}$ \\ 1- Forensic Medicine and Clinical Toxicology Department, Benha Faculty of Medicine, \\ Benha University, Benha, Egypt \\ 2-Department of histology and cell biology Benha Faculty of Medicine, Benha University, \\ Benha, Egypt. \\ 3- Department of Medical Biochemistry \& Molecular Biology, Benha Faculty of Medicine, \\ Benha University,Benha, Egypt

$$
\text { E-mail*sanya.khairy@gmail.com }
$$

\section{ARTICLEINFO}

Article History

Received:5/9/2021

Accepted:11/11/2021

\section{Keywords:}

MSG, GABA, Oxidative Stress,

Jojoba oil, NF $\kappa \mathrm{B}$, GLUT4

\section{INTRODUCTION}

Background: Monosodium glutamate (MSG) is one of the most used food additives that disrupt the metabolism and the functions of many organs, including the heart, liver, brain, and others. Jojoba is a plant with high oil content in its seeds and special antioxidant and anti-inflammatory characters that make it convenient for medical uses as a natural plant. GLUT 4 is useful for "deep" glucose transport during raised energy demand. Aim: To evaluate the antioxidant activity of jojoba oil and its role against MSGinduced toxicity in rats by improving metabolic dysfunction in the brain and heart and minimizing pathological changes. Materials and Methods: Thirty-two male albino adult rats were assigned randomly to four equal groups. Group I was given distilled water (control group). Group II was given a standard diet with 2.5 percent jojoba oil added. MSG $(4 \mathrm{~g} / \mathrm{kg}$ ) dissolved in distilled water was given orally to group III. Group IV received MSG $(4 \mathrm{~g} / \mathrm{kg}$ ) diluted in distilled water and was also fed a basic diet with 2.5 percent jojoba oil. After two months, blood samples were taken to measure the expression of NFאB and GLUT4 genes, free fatty acids (FFA), troponin I, CK-MB, cytokines, oxidative stress markers, and GABA neurotransmitters. Histopathological study of the heart and brain tissues was also done. Results: MSG increases NF $\kappa$ B expression, Troponin I, CK-MB, FFA, TNF $\alpha$, IL6, Caspase3, and MDA compared to normal control rats. Significant depletion of Catalase, GABA neurotransmitter with downregulation of GLUT4 gene expression was noted. Histopathological alterations in the brain and cardiac tissues of MSG-treated rats were also noted. In contrast, treatment with jojoba oil greatly attenuated these toxic effects. Conclusion: Because of its antioxidant properties and ameliorating metabolic properties, jojoba oil showed significant protection against MSGinduced cardiac and neurotoxicity.

With the fast pace of life, people do not have time to prepare healthy meals. Instead, their main dependence has become on fast food, which lacks nutrients useful for their 
bodies, and they use food additives which lead to increasing the toxic effects of these meals (Banerjee et al., 2020). Monosodium glutamate (MSG, C5H8NO4Na, encoded as E621, China salt) is sodium salt of glutamic acid. It is a food additive for flavor enhancement used in a wide range of foods (Bhattacharya et al., 2011). Food additives are used in the food industry in a minimal amount to enhance its taste, appearance, and texture (Moldes et al., 2017). However, this may lead to a great problem if there is a frequent intake of these small amounts on a regular dietary basis (Blaylock, 2007).

Currently, monosodium glutamate is widely sold in Egyptian stores, and many Egyptians use it daily in their food (Mohamed, 2012).

The safe and toxic doses of monosodium glutamate in human food are still controversial (Hamzaa and Diabb, 2020). Its excessive use in food needs to be evaluated, and there is a raised concern about its increased level in the blood (Rosa et al., 2018).

Despite its global use as a food flavor, reports state that monosodium glutamate is toxic to humans and animals at high doses (Tawfik and Al-Badr, 2012). Recent studies showed that monosodium glutamate caused neurodegenerative damage, cardiovascular toxicity, nephrotoxicity, and hepatotoxicity (Zanfirescu et al., 2019). Consuming a high amount of MSG causes oxidative stress in many organs with many side effects (Hazzaa et al., 2020), which is considered the main mechanism of MSG-induced toxicities (Singh and Ahluwalia, 2012).

GLUT4 is a metabolic regulator that promotes glycolysis in firing neurons to meet activity-driven ATP demand at nerve terminals (Ashrafi et al., 2017). There are twelve GLUTs; the most common are GLUT1, GLUT4, and GLUT8 in the heart (Aerni-Flessner et al., 2012).

The nuclear factor-kappa B family $(\mathrm{NF}-\kappa \mathrm{B})$ is a protein complex that functions as a primary transcription factor and a fast messenger responding to harmful cell stimuli such as inflammation (Pateras et al., 2014). Upon activation, it translocates into the nucleus and binds to the promoter regions of pro-inflammatory genes such as TNF- $\alpha$, interleukin- 6 (IL6 ), and IL-8. NF-kB is also activated in neuropathological disorders, neurons, and glial cells (Engelmann et al., 2014). NF-B signaling, which mediates inflammatory processes (Moretti et al., 2012), also functions as a regulator and integrator of energy metabolism, balancing glycolysis utilization and mitochondrial respiration (Zhong et al., 2016).

Nowadays, natural plant oils are globally utilized for medical purposes as they are easy to get, effective, and cheap. Numerous oils have anti-inflammatory and antioxidant components, which makes them appropriate for medical uses. Jojoba (Simmondsia chinensis) is one of these natural Simmondsiaceae plants. It is a woody plant that remains green throughout the year and grows to around three meters in height (Phillips and Comus, 2000).

Jojoba can grow in arid or semiarid soil with a warm and dry environment. It began to be cultivated in many countries such as Egypt, Tunisia, Saudi Arabia, and India (AbdelMageed et al., 2014). Currently, it is grown in the Ismailia Desert in Egypt (El Mallah and El-Shami, 2009).

Compared to other oils, jojoba oil has a characteristic component as it contains long monounsaturated esters. Others are mostly composed of triglycerides; this offers jojoba oil special properties critical for manufacturing pharmaceutical preparations (Sánchez et al., 2016). Because jojoba contains lipoxygenase inhibitors, it can protect against oxidative stress generated by free radicals (Abdel-Mageed et al., 2014). Additionally, jojoba oil has been shown to decrease leukotriene formation and thereby ROS production (Haeggström and Funk, 2011). Moreover, its antioxidant ability has been demonstrated through nitric oxide and DPPH scavenging effects (Manoharan et al., 2016). 
Attention has recently been shifted to natural antioxidants, as they have minimal or no side effects and help maintain normal health wellbeing. Therefore, the current study aimed to evaluate jojoba oil's antioxidant and scavenging activity and its role against MSG-induced cardio and neurotoxicity in rats.

\section{MATERIALS AND METHODS}

\section{Chemicals:}

- MSG was obtained as a powder from Sigma-Aldrich (St. Louis, MO, USA) and dissolved in a normal saline solution.

-Jojoba oil was obtained from Egypt's Pure Life Company.

- The rest of the chemicals were of analytical grade.

\section{Animals:}

Thirty-two male albino adult Sprague-Dawley rats, aged 2-3 months and weighing 180 - 220 gm, were purchased from the Experimental Animal Breeding Farm (HelwanCairo). They were housed as eight per cage at room temperature in a well-ventilated area at the Benha Faculty of Medicine, department of pharmacology. They were provided two weeks of acclimatization with access to free water and standard meals on a 12-hour light/12-hour dark schedule and received their doses simultaneously (12 P.M.). Throughout the experiment, animals were handled humanely following the Benha Faculty of Medicine's protocol for treating experimental animals. Every attempt to decrease the number of utilized animals and their suffering was made.

\section{Experimental Design:}

The rats were randomly assigned into one of four equal groups and given MSG and jojoba oil for two consecutive months as follows:

Group I: served as control and received distilled water.

Group II: Rats were fed a standard diet mixed with 2.5 percent jojoba oil (Nassar et al., 2017).

Group III: rats were orally administered MSG ( $4 \mathrm{~g} / \mathrm{kg} /$ day) dissolved in distilled water by a nasogastric tube based on the method of Onyema et al. (2012).

Group IV: received MSG $(4 \mathrm{~g} / \mathrm{kg})$ dissolved in distilled water orally by nasogastric tube and fed on a standard diet mixed with 2.5 percent jojoba oil simultaneously.

The LD50 of MSG in rats is $15-18 \mathrm{~g} / \mathrm{kg}$ BW, according to Walker and Lupien (2000). Therefore, $4 \mathrm{~g} / \mathrm{kg}$ equals $23 \%$ of the rat's oral LD50.

\section{Blood Sample:}

All animals were fasted for 6 hours and then anesthetized with light ether at the end of the experiment ( 2 months). A midline abdominal incision was made, and blood samples $(3 \mathrm{~mL})$ were collected from the abdominal aorta in dry test tubes. Serum was separated immediately by centrifugation for 20 minutes at $3000 \mathrm{rpm}$ in a refrigerated centrifuge $\left(4^{\circ} \mathrm{C} 4 \mathrm{C}\right)$. After rapid freezing, the serum was preserved in liquid nitrogen $\left(80^{\circ} \mathrm{C}\right)$ for the determination of GABA neurotransmitter, troponin I, tumor necrosis factor (TNF $\alpha)$, CKMB, MDA, IL6, free fatty acids (FFA), caspase 3, catalase, and expression of NF- $\kappa B$, GLUT4 genes by RT- PCR.

Diamond Diagnostics kits (Cairo, Egypt) were used to measure troponin I and CKMB. According to the manufacturer's instructions, MDA, catalase, caspase-3, TNF, and IL6 were determined through a colorimetric method (Bio diagnostics, Dokki, Giza, Egypt). GABA detection was done using Quick Detect ${ }^{\mathrm{TM}}$ GABA ELISA Kit Biovision Catalog \#: E4455 and level of serum FFA were detected by free fatty acid assay kit quantification ab65341 as indicated by the manufacturers. 


\section{RNA Extraction, Reverse Transcription, Quantitative Analysis of Transcripts Using qRT-PCR:}

According to the manufacturer's instructions, total RNA was extracted from serum using the RNA Mini Kit (Qiagen, USA). Using Nanodrop (USA), the quality and quantity of RNA were determined. The $260 \mathrm{~nm}$ to $280 \mathrm{~nm}$ readings (A260/280) ratio indicates the RNA's purity. Pure RNA had a 280/260 ratio of 1.9-2.3(OD260/OD280). The concentration and purity of the RNA recovered were assessed using the 260/230 nm and $280 / 260 \mathrm{~nm}$ absorbance ratios. With the quantiscript cDNA synthesis kit, RNA was reverse transcribed to cDNA (Qiagen, USA). After 15 minutes of reverse transcription at $42^{\circ} \mathrm{C}$, the RT enzyme was inactivated with three-minute incubation at $95^{\circ} \mathrm{C}$. Until it was used, the cDNA was kept at $-70^{\circ} \mathrm{C}$. Real-time PCR was done under the following conditions: 40 cycles at $95^{\circ} \mathrm{C}$ for 5 minutes for the Hotstar Taq polymerase activation, 10 seconds at $95^{\circ} \mathrm{C}$ for denaturation, and 30 seconds at $60^{\circ} \mathrm{C}$ for annealing and extension.

Table 1: Primers sequences of NF- $\kappa B$, GLUT 4 and GAPDH

\begin{tabular}{|l|l|}
\hline NF-אB & $\begin{array}{l}\text { Forward Sequence CAC CAA AGA CCC ACC TCA } \\
\text { Reverse Sequence GGA CCG CAT TCA AGT CAT }\end{array}$ \\
\hline GLUT 4 & $\begin{array}{l}\text { Forward Sequence 'GAGCCTGAATGCTAATGGAG' } \\
\text { Reverse Sequence }\end{array}$ \\
\hline GAPDH & $\begin{array}{l}\text { Forward Sequence } \\
\text { Reverse Sequence AGTGCCAGCCTCGTCTCAT }\end{array}$ \\
\hline
\end{tabular}

Relative quantification of NF- $\kappa \mathrm{B}$, GLUT 4 and GAPDH was performed with the $2^{-\mathrm{ddCt}}$ method, sequence shown in table (1) and analyzed by ABI prism 7500 . The Boxplot software and values were normalized to the quantity of GAPDH

\section{Histopathological Study:}

Following blood sampling, the rats were decapitated, and the brain and heart tissues were immediately isolated, washed with saline, and fixed in $10 \%$ buffered formalin, processed, and underwent embedding in paraffin. Serial sections of $5 \mathrm{~m}$ thickness were cut and stained with Haematoxylin and Eosin (H\&E) according to the method described by Bancroft and Gamble (2008), specimens of brain and heart tissues for toluidine blue staining were postfixed in 1\% osmium tetroxide (Biochrom AG), dehydrated through graded alcohols and embedded in paraffin according to the method described by Bancroft and Gamble (2008). Microscopic photographs were taken for histopathological examination.

\section{Statistical Analysis:}

SPSS version 25 (IBM, Armonk, New York, United States) was used to collect, tabulate, and analyze the data. To summarize numerical data, means and standard deviations or medians and interquartile ranges were used. To compare the study groups, ANOVA or the Kruskal-Wallis test were used. Bonferroni's method was used for post-hoc analysis. All statistical tests were conducted on a two-sided basis. P values less than 0.05 were considered significant.

\section{RESULTS}

Table (2) shows a statistically significant increase in NF-B gene expression $(\mathrm{p}<0.05)$ and a highly significant decrease in GLUT4 gene expression $(\mathrm{p}<0.05)$ in comparison to the control group. 


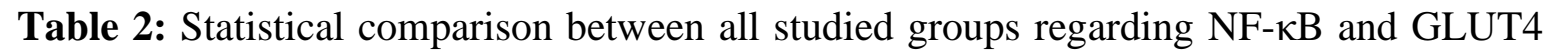
genes by ANOVA test

\begin{tabular}{|c|c|c|c|c|c|}
\hline & $\begin{array}{c}\text { Group (I) } \\
\text { Control group }\end{array}$ & $\begin{array}{c}\text { Group (II) } \\
\text { Jojoba Oil group }\end{array}$ & $\begin{array}{c}\text { Group (III) } \\
\text { MSG group }\end{array}$ & $\begin{array}{c}\text { Group (IV) } \\
\text { MSG + Jojba } \\
\text { oil group }\end{array}$ & P value \\
\hline NF-kB gene & $\begin{array}{c}0.176 €^{*} \\
(0.164-1.231)\end{array}$ & $\begin{array}{c}0.526 €^{*} \\
(0.164-1.125)\end{array}$ & $\begin{array}{c}4.249 \$^{\wedge} \\
(3.299-6.234)\end{array}$ & $\begin{array}{c}2.368 \\
(1.164-3.173\end{array}$ & $<0.001^{* *}$ \\
\hline $\begin{array}{c}\text { GLUT4 } \\
\text { gene }\end{array}$ & $\begin{array}{c}5.234 €^{*} \\
(4.239-6.234)\end{array}$ & $\begin{array}{c}4.749 €^{*} \\
(4.234-6.234)\end{array}$ & $\begin{array}{c}0.614 \$^{\wedge} \\
(0.167-1.972)\end{array}$ & $\begin{array}{c}3.36 \\
(2.183-4.194)\end{array}$ & $<0.001^{* *}$ \\
\hline
\end{tabular}

Data were presented as median (IQR). Kruskal-Wallis test was used. All post hoc comparisons were Bonferroni adjusted. Number of rats in each group $=8$

The mean difference is significant at $<0.05$ level.

highly significant $(* *)$

$\$$ : indicate significant change as compared with a group (I)

$\wedge$ : indicate significant change as compared with a group (II)

$€$ : indicate significant change as compared with a group (III)

*: indicate significant change as compared with a group (IV)

Table (3) shows that intoxication with MSG resulted in a highly significant $(\mathrm{p}<0.05)$ rise in cardiac biomarkers (Troponin I \& CK-MB) when compared to the control group. On simultaneous administration of jojoba oil with MSG, Troponin I and CK-MB levels decreased significantly $(\mathrm{p}<0.05)$ compared to the MSG group. Additionally, there was a highly significant $(\mathrm{p}<0.05)$ increase in FFA in the MSG group compared to the control group. However, when jojoba oil was simultaneously administered with MSG, there was a highly significant $(\mathrm{p}<0.05)$ reduction in its level compared to the MSG group.

Table 3: Statistical comparison between all studied groups regarding cardiac biomarkers (Troponin I, CK-MB) and FFA by ANOVA test.

\begin{tabular}{|c|c|c|c|c|c|}
\hline & $\begin{array}{c}\text { Group (I) } \\
\text { Control group }\end{array}$ & $\begin{array}{c}\text { Group (II) } \\
\text { Jojoba Oil group }\end{array}$ & $\begin{array}{c}\text { Group (III) } \\
\text { MSG group }\end{array}$ & $\begin{array}{c}\text { Group (IV) } \\
\text { MSG + Jojba } \\
\text { oil group }\end{array}$ & P value \\
\hline $\begin{array}{c}\text { Troponin I } \\
\text { (ng/ml) }\end{array}$ & $27 \pm 3 €^{*}$ & $30 \pm 4 €^{*}$ & $82 \pm 7 \$^{\wedge *}$ & $45 \pm 3 \$^{\wedge} €$ & $<0.001^{* *}$ \\
\hline $\begin{array}{c}\text { CK- MB } \\
\text { (IU/L) }\end{array}$ & $532 \pm 13 €^{*}$ & $544 \pm 12 €^{*}$ & $2495 \pm 134 \$^{\wedge *}$ & $940 \pm 14 \$^{\wedge} €$ & $<0.001^{* *}$ \\
\hline $\begin{array}{c}\text { FFA } \\
(\mathbf{m E q} / \mathbf{m l})\end{array}$ & $0.78 \pm 0.05 €^{*}$ & $0.78 \pm 0.05 €^{*}$ & $3.24 \pm 0.38 \$^{\wedge *}$ & $1.81 \pm 0.4 \$^{\wedge} €$ & $<0.001^{* *}$ \\
\hline
\end{tabular}

All values are expressed as mean $\pm \mathrm{SD}$

Number of rats in each group $=8$

The mean difference is significant at $<0.05$ level.

highly significant $(* *)$

$\$$ : indicate significant change as compared with a group (I)

$\wedge$ : indicate significant change as compared with a group (II)

$€$ : indicate significant change as compared with a group (III)

*: indicate significant change as compared with a group (IV)

As shown in table (4), the MSG intoxicated group showed a highly statistically significant $(\mathrm{p}<0.05)$ increase in TNF, IL6, and caspase 3 levels compared to the control group.

But when jojoba oil was simultaneously given with MSG, there was a highly statistically significant reduction in their levels compared to the MSG group ( $p<0.05)$. 
Table 4: Statistical comparison between all studied groups regarding TNF $\alpha$, IL6 and Caspase 3 by ANOVA test

\begin{tabular}{|c|c|c|c|c|c|}
\hline & $\begin{array}{c}\text { Group (I) } \\
\text { Control group }\end{array}$ & $\begin{array}{c}\text { Group (II) } \\
\text { Jojoba Oil group }\end{array}$ & $\begin{array}{c}\text { Group (III) } \\
\text { MSG group }\end{array}$ & $\begin{array}{c}\text { Group (IV) } \\
\text { MSG + Jojba } \\
\text { oil group }\end{array}$ & P value \\
\hline $\begin{array}{c}\text { TNFa } \\
(\mathbf{p g} / \mathbf{m l})\end{array}$ & $82.6 \pm 2.9 €^{*}$ & $84.3 \pm 3.2 €^{*}$ & $394 \pm 6.1 \AA^{\wedge *}$ & $150.1 \pm 4.6 \$^{\wedge} €$ & $<0.001^{* *}$ \\
\hline $\begin{array}{c}\text { IL6 } \\
\text { (Pg/ml) }\end{array}$ & $18.9 \pm 2 €^{*}$ & $20.8 \pm 2.3 €^{*}$ & $74.9 \pm 3.4 \AA^{\wedge *}$ & $38 \pm 3.8 \$^{\wedge} €$ & $<0.001^{* *}$ \\
\hline $\begin{array}{c}\text { Caspase 3 } \\
\text { (IU/m) }\end{array}$ & $0.72 \pm 0.13 €^{*}$ & $1.01 \pm 0.12 €^{*}$ & $12.16 \pm 0.2 \$^{\wedge *}$ & $6.01 \pm 1.06 \$^{\wedge} €$ & $<0.001^{* *}$ \\
\hline
\end{tabular}

All values are expressed as mean \pm SD

Number of rats in each group $=8$

The mean difference is significant at $<0.05$ level.

highly significant $(* *)$

$\$$ : indicate significant change as compared with a group (I)

$\wedge$ : indicate significant change as compared with a group (II)

$€$ : indicate significant change as compared with a group (III)

*: indicate significant change as compared with a group (IV)

Table (5) demonstrated the ameliorative impact of jojoba oil on the oxidative stress generated by MSG (5). Compared to the control group, the MSG-intoxicated group showed a highly significant reduction in plasma CAT levels and a highly significant increase in plasma MDA levels $(p<0.05)$. When jojoba oil was given simultaneously with MSG, improvement was noted. Compared to the MSG group, there was a highly significant rise in plasma CAT levels and a highly significant $(\mathrm{p}<0.05)$ decrease in plasma MDA levels. Additionally, in comparison to the control group, the Jojoba group demonstrated a highly significant $(\mathrm{p}<0.05)$ rise in plasma CAT levels and a highly significant $(\mathrm{p}<0.05)$ drop in plasma MDA levels.

Table 5: Statistical comparison between all studied groups regarding MDA and Catalase by ANOVA test.

\begin{tabular}{|c|c|c|c|c|c|}
\hline & $\begin{array}{c}\text { Group (I) } \\
\text { Control group }\end{array}$ & $\begin{array}{c}\text { Group (II) } \\
\text { Jojoba Oil group }\end{array}$ & $\begin{array}{c}\text { Group (III) } \\
\text { MSG group }\end{array}$ & $\begin{array}{c}\text { Group (IV) } \\
\text { MSG + Jojba } \\
\text { oil group }\end{array}$ & P value \\
\hline $\begin{array}{c}\text { MDA } \\
\text { (nmole/ml) }\end{array}$ & $\mathbf{3 6 . 8} \pm 2.4 €^{*}$ & $37.6 \pm 2.5 €^{*}$ & $91.4 \pm 5.3 \$^{\wedge} *$ & $63.8 \pm 3.5 \$^{\wedge} €$ & $<0.001^{* *}$ \\
\hline $\begin{array}{c}\text { Catalase } \\
\text { (ng/ml) }\end{array}$ & $36.4 \pm 3 €^{*}$ & $38.1 \pm 3.3 €^{*}$ & $10.3 \pm 1.5 \$^{\wedge} *$ & $\mathbf{2 0 . 3} \pm 1.4 \$^{\wedge} €$ & $<0.001^{* *}$ \\
\hline
\end{tabular}

All values are expressed as mean \pm SD

Number of rats in each group $=8$

The mean difference is significant at $<0.05$ level.

highly significant $(* *)$

$\$$ : indicate significant change as compared with a group (I)

$\wedge$ : indicate significant change as compared with a group (II)

$€$ : indicate significant change as compared with a group (III)

*: indicate significant change as compared with a group (IV)

As shown in table (6), MSG intoxication caused a highly significant decline in GABA levels compared to the control group. In contrast, when jojoba oil was simultaneously administered with MSG, a highly significant $(\mathrm{p}<0.05)$ rise in GABA level was observed compared to the MSG group. 
Table 6: Statistical comparison between all studied groups regarding GABA neurotransmitter by ANOVA test.

\begin{tabular}{|c|c|c|c|c|c|}
\hline & $\begin{array}{c}\text { Group (I) } \\
\text { Control group }\end{array}$ & $\begin{array}{c}\text { Group (II) } \\
\text { Jojoba Oil group }\end{array}$ & $\begin{array}{c}\text { Group (III) } \\
\text { MSG group }\end{array}$ & $\begin{array}{c}\text { Group (IV) } \\
\text { MSG + Jojba } \\
\text { oil group }\end{array}$ & P value \\
\hline $\begin{array}{c}\text { GABA } \\
(\mathbf{p g} / \mathbf{m l})\end{array}$ & $376 \pm 21 €^{*}$ & $374 \pm 18 €^{*}$ & $210 \pm 21 \$^{\wedge} *$ & $296 \pm 14 \$ \uparrow$ & $<0.001^{* *}$ \\
\hline
\end{tabular}

All values are expressed as mean $\pm \mathrm{SD}$

Number of rats in each group $=8$

The mean difference is significant at $<0.05$ level.

highly significant $(* *)$

$\$$ : indicate significant change as compared with a group (I)

$\wedge$ : indicate significant change as compared with a group (II)

$€$ : indicate significant change as compared with a group (III)

*: indicate significant change as compared with a group (IV)

\section{Histopathological Results:}

Concerning the histopathological study by Haematoxylin and Eosin (H\& E) stain on cardiac tissue, the control group (group I) showed cylindrical muscle fibers with acidophilic sarcoplasm and a central oval nucleus (Fig. 1A); the cardiac tissue of jojoba oil-treated rats (group II) revealed near-normal cardiac tissue structure (Fig. 1B); the cardiac tissue of MSG-treated rat (group III) showed necrosis in cardiac muscles with apparent inflammatory infiltration and hemorrhage in all heart muscles (Fig. 1C) ; the cardiac tissue of rats co-treated with MSG and jojoba oil (group IV) showed improvement in the form of less necrosis, less inflammatory infiltration, and less hemorrhage (Fig. 1D).

While concerning the histopathological study by Haematoxylin and Eosin (H\& E) stain on the cerebral cortex of the rats brain, in Figure (2A), the control group showed normal neurocytes and glial cells within a neurofibrillary background; jojoba oil-treated rats (group II) revealed near-normal brain tissue structure (Fig. 2B); the cerebral cortex of MSG-treated rat (group III) showed loss of normal structure with pyknotic nucleus, vacuolated cells, and proliferated vascular spaces (Fig. 2C); cerebral cortex in rat cotreated with MSG and jojoba oil (group IV) showed improvement except from few pyknotic nucleus and few vacuolated cells (Fig. 2D ).

The histopathological study with toluidine blue on cardiac tissue showed the control group (group I) of cardiac muscle fibers with a central oval nucleus (Fig. 3A); the cardiac tissue of jojoba oil-treated rats (group II) revealed near-normal cardiac tissue structure (Fig. 3B); the cardiac tissue of MSG-treated rat (group III) showed vacuolations in between cardiac cells (Fig. 3C); the cardiac tissue of rats co-treated with MSG and jojoba oil (group IV) showed improvement in the form of less vacuolations (Fig. 3D).

While the histopathological study with toluidine blue on cerebral cortex tissue showed the control group (group I) with normal neurocytes and glial cells in the (Fig. 4A); section of the cerebral cortex of jojoba oil-treated rats (group II) revealed near- normal neurocytes and glial cells (Fig. 4B); section of the cerebral cortex of MSG-treated rat (group III) showed loss of normal structure with many vacuolations and neuronal cell swelling and rounding with displacement of the pyknotic nucleus (Fig. 4C); section of rat cerebral cortex co-treated with MSG and jojoba oil (group IV) showed improvement of neurocytes with few vacuolations (Fig. 4D). 


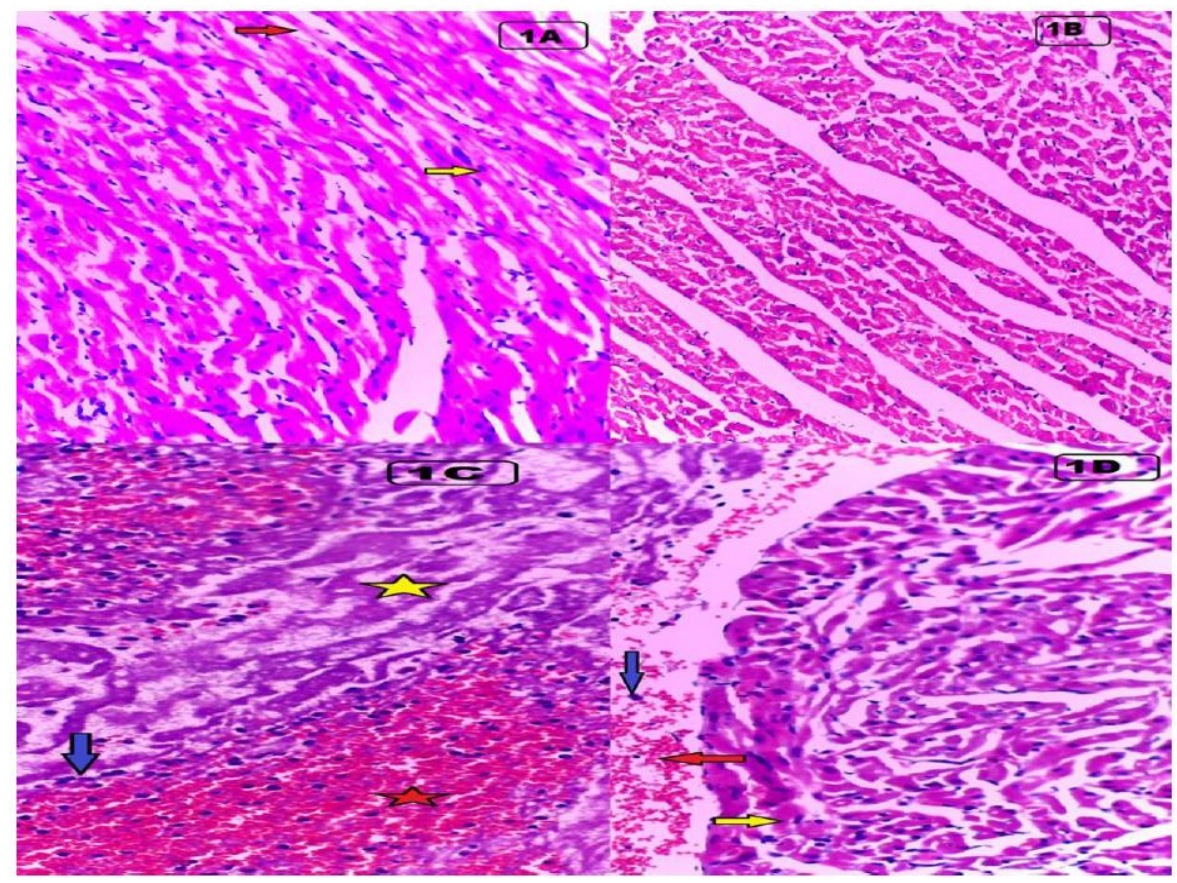

Fig. 1: (A) the control group showed typical cylindrical muscle fibers with acidophilic sarcoplasm (red arrow) and a central oval nucleus (yellow arrow) in the histological slides of the rat heart stained with hematoxylin and eosin (H\&E x200); (B) section of the cardiac tissue of jojoba oil-treated rats revealed nearnormal cardiac tissue structure (H\&E x200); (C) section of the cardiac tissue of MSG-treated rat showed necrosis in cardiac muscles (yellow star) with apparent inflammatory infiltration (blue arrow) and hemorrhage in all heart muscles (red star) (H\&E x200); (D) section of the cardiac tissue of rats co-treated with MSG and jojoba oil showed improvement in the form of less necrosis (yellow arrow), less inflammatory infiltration (blue arrow), and less hemorrhage (red arrow) (H\&E x200).

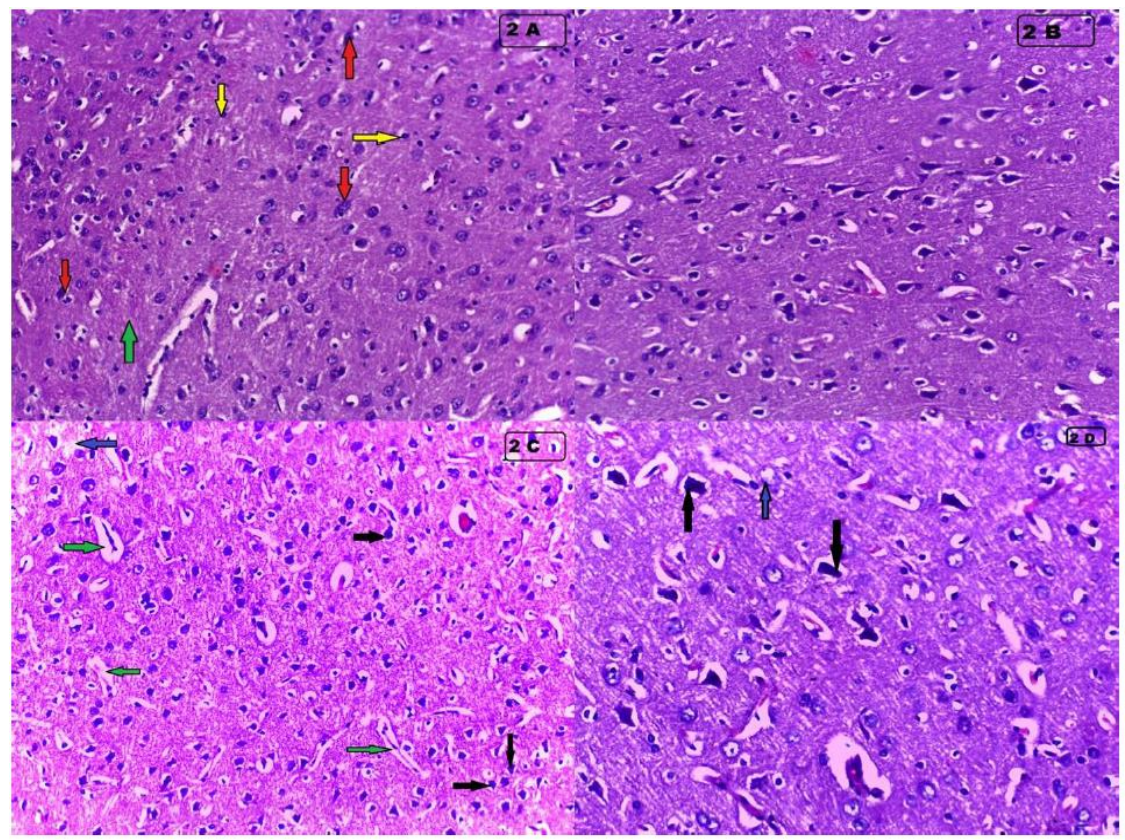

Fig. 2: the control group (A) showed normal neurocytes (red arrow) and glial cells (yellow arrow) within a neurofibrillary background (green arrow) in the histopathological slides of the cerebral cortex of the rats brain stained with hematoxylin and eosin (H\&E x200); (B) section from jojoba oil-treated rats revealed near-normal brain tissue structure (H\&E x200); (C) section of the cerebral cortex of MSG-treated rat showed loss of normal structure with pyknotic nucleus (black arrow), vacuolated cells (blue arrow), and proliferated vascular spaces (green arrow) (H\&E x 200); (D) section of rat cerebral cortex co-treated with MSG and jojoba oil showed improvement except from few pyknotic nucleus (black arrow) and few vacuolated cells (blue arrow) (H\&E x200). 


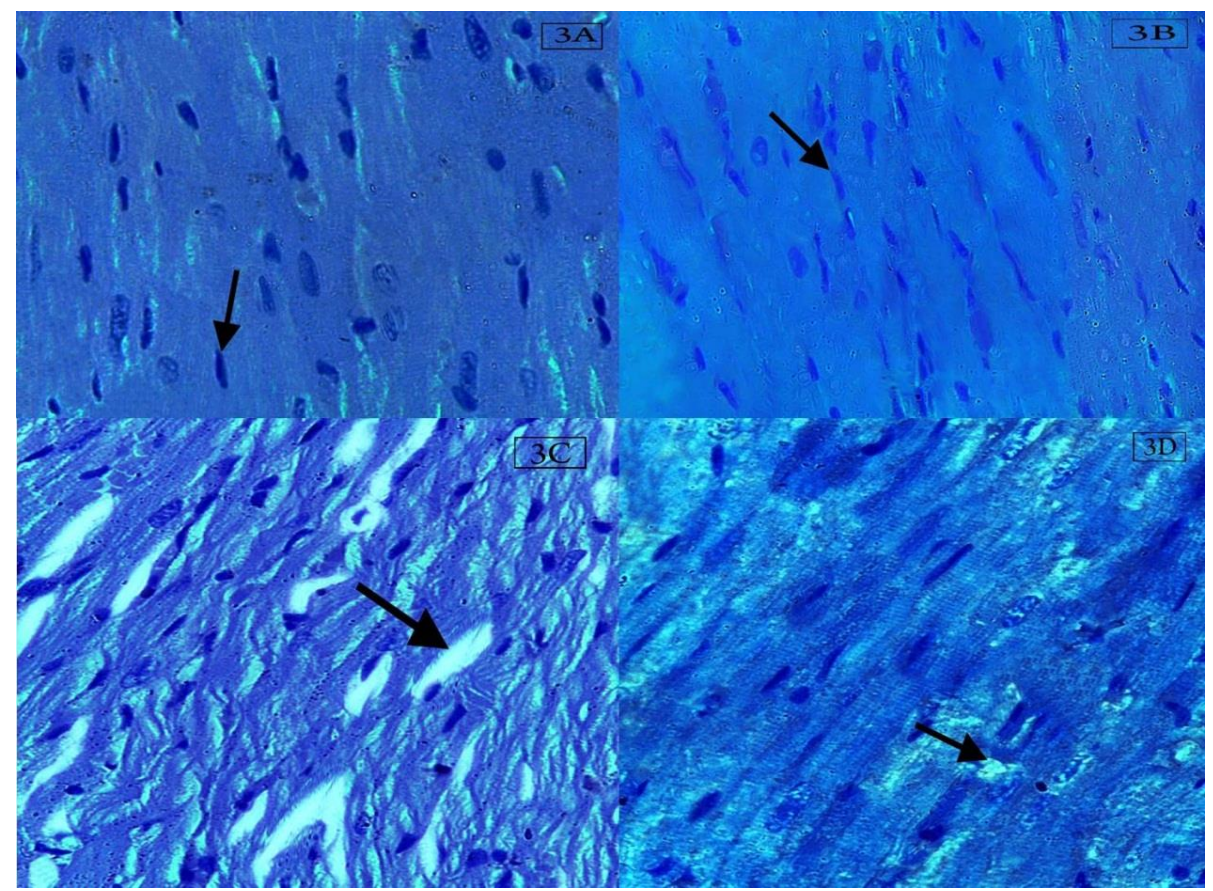

Fig. 3: The control group (A) showed cardiac muscle fibers with a central oval nucleus (arrow) in the histological slides of the rat heart stained with toluidine blue (TB x400); (B) section of the cardiac tissue of jojoba oil-treated rats revealed near-normal cardiac tissue structure (TB x400); (C) section of the cardiac tissue of MSG-treated rat showed vacuolations in between cardiac cells (arrow) (TB x400); (D) section of the cardiac tissue of rats co-treated with MSG and jojoba oil showed improvement in the form of less vacuolations (arrow), (TB x400).

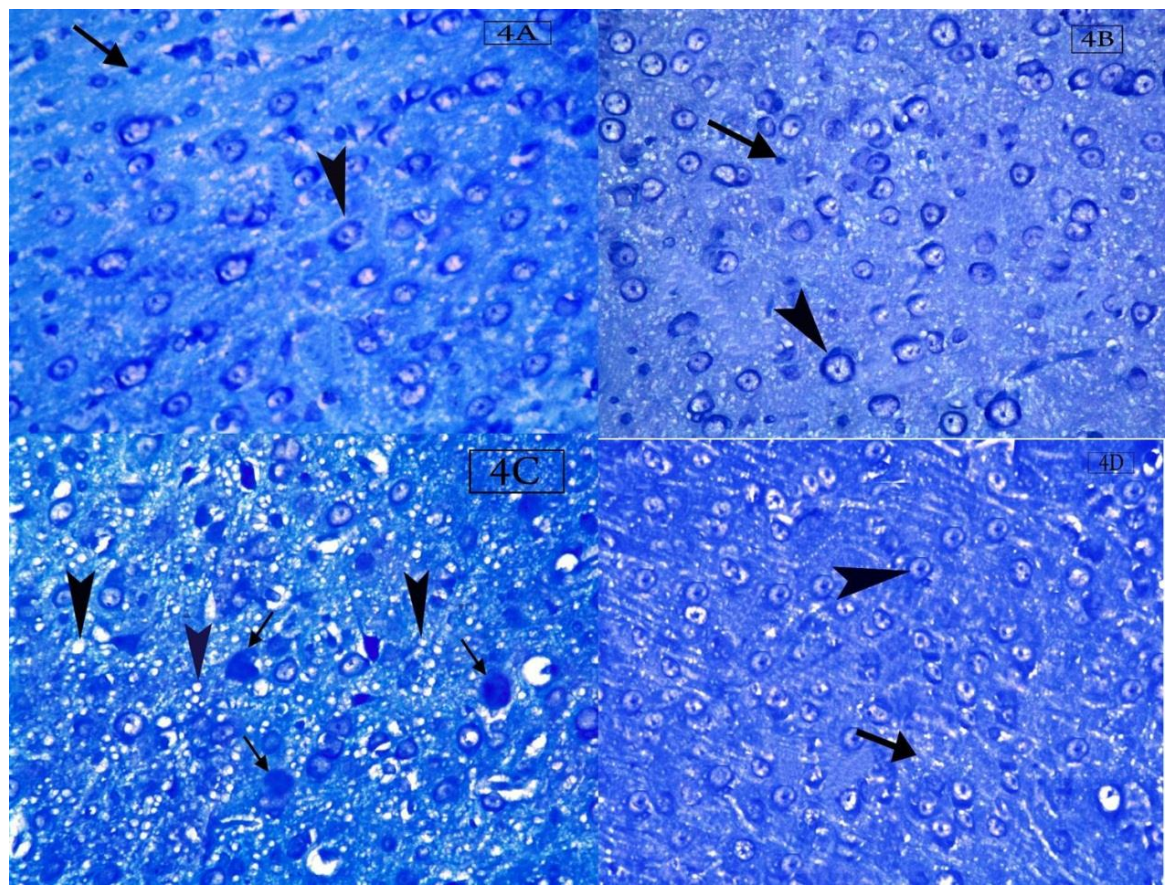

Fig. 4: the control group (A) showed normal neurocytes (head arrow) and glial cells (arrow) in the histopathological slides of the cerebral cortex of the rats brain stained with toluidine blue (TB x400); (B) section from jojoba oil-treated rats revealed near- normal neurocytes (head arrow) and glial cells (arrow) (TB x400); (C) section of the cerebral cortex of MSG-treated rat showed loss of normal structure with many vacuolations (head arrow), neuronal cell swelling and rounding with displacement of the pyknotic nucleus (arrow) (TB x 400); (D) section of rat cerebral cortex co-treated with MSG and jojoba oil showed improvement of neurocytes (head arrow) with few vacuolations (arrow) (TB x400). 


\section{DISCUSSION}

Monosodium glutamate is one of the most often used food additives in fast food worldwide, with different concentrations (Helal et al., 2019). The safe and toxic doses of monosodium glutamate in human food are still controversial (Hamzaa and Diabb, 2020). Its excessive use in food needs to be evaluated, and raised the concern about its increased use level in the blood (Rosa et al., 2018). Despite its global use as a food flavor, there are reports that monosodium glutamate is toxic to humans and animals at high doses (Tawfik and Al-Badr, 2012). Recent studies showed that monosodium glutamate caused diabetes, neurodegenerative damage, cardiovascular toxicity, nephrotoxicity, and hepatotoxicity (Zanfirescu et al., 2019).

When compared to other oils, jojoba oil has a characteristic component. It contains long monounsaturated esters. Others are primarily triglycerides, and this offers jojoba oil unique properties essential for producing pharmacological preparations (Sánchez et al., 2016). Additionally, Badr et al. (2017) revealed that jojoba oil contained a high concentration of total phenolic and flavonoid compounds, providing superior antioxidant properties to vitamin $\mathrm{C}$.

Jojoba oil ameliorated the toxic effects of MSG in the present study, as evidenced by improvement levels of troponin I, CK-MB, FFA, TNF $\alpha$, IL6, Caspase 3, MDA, Catalase, and expression of NF- $\kappa \mathrm{B}$ and GLUT4 genes. Furthermore, jojoba oil ameliorated the histopathological changes induced by MSG in the heart and brain.

Physiological adaptation and pathological changes occur due to changes in genes that regulate essential cellular processes; therefore, determining variables that regulate gene expression is critical for comprehending the disease process (Lee and Young, 2013; Vaquerizas et al., 2009).

Gene expression changes may occur early in the disease, but histopathogenic changes frequently occur over a long time. As a result, symptoms become apparent after permanent tissue damage has occurred, limiting efficient management options and increasing the burden on population health and healthcare (Jardim et al., 2019). Thus, identifying the molecular mechanisms behind these harmful changes will improve our understanding of these diseases and assist early detection and treatment to limit pathogenic changes before irreversible damage occurs. Since the histopathological changes that drive chronic diseases are the result of altered gene expression (Lee and Young, 2013), identifying the tissue-specific transcription factors that regulate these cellular genes will shed light on the mechanisms underlying the pathological changes associated with common diseases (Blaschke et al., 2006; Kadonaga, 2004).

The heart consumes more energy than any other organ that derives its energy from metabolic substrates. Free fatty acids and glucose are the major substrates. Due to the hydrophilic nature of the lipid bilayer, glucose cannot be absorbed by the cell via glucose transporters ( Szablewski, 2017).

GLUT1 and GLUT4 are the most abundant isoforms of glucose transporters (Pereira et al., 2014). GLUT4 is the major isoform in the human heart, representing approximately $70 \%$ of the total glucose transporters. The most important role in myocardial glucose flux is played by GLUT 1 and GLUT 4 (Szablewski, 2017). In the brain, glucose transporters play important roles in different brain functions in health and disease. Facilitative diffusion transporters in the brain include GLUT1, GLUT2, GLUT3, and GLUT4 (Koepsell, 2020).

The current results revealed that administrating monosodium glutamate caused upregulation of nuclear factor kappa $(\mathrm{NF}-\kappa \mathrm{B})$ with metabolic alternation in cytokines, oxidative stress, and Caspase3. Such results were previously provided by Albensi and 
Mattson (2000). They stated that NF-B is a signaling network involved in complicated biological signaling processes, such as energy metabolism, cell apoptosis, proliferation, and inflammation. Additionally, it is one of the cellular sensors that respond to oxidative stress and regulates malonaldehyde production (MDA) (Wende et al., 2017). Also, NF-кB acts as a master regulator of biochemical cascades (Mattson et al., 2000; Lamas et al., 2003; Mauro et al., 2011; Moretti et al., 2012).

The activation of NF-B by oxidative stress, cytokines, chemokines, neurotransmitters, neurotropic factors, and neurotoxins results in the generation of proinflammatory mediators, leading to creating a self-propagating vicious circle (Hayden and Ghosh, 2012). TNF $\alpha$ acts as an NF- $\mathrm{kB}$ activator, which participates in an extrinsic

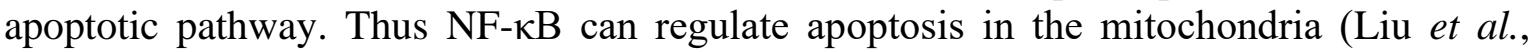
2004).

These results agreed with (Alalwani 2014; Abudunaibi et al.,2018; Umukoro et al., 2015; Vega and Kelly, 2017), who reported the role of the nuclear receptor in controlling energy metabolism in the normal and diseased heart.

The existing results verified that alternation in the expression of GLUT4 is synchronous with alternation of biochemical parameters as the increase in caspase 3 marker of apoptosis. Also, this result agreed with that published by Henning et al. (1996), who stated that decreased expression of GLUT4 may be harmful to cardiac glucose metabolism.

Wende et al. (2017) and Szablewski (2017) revealed that GLUT4 is a crucial regulator of glucose entrance into the heart. The expression of GLUT4 is required for the cardiac responses to chronic pathological stress or intermittent physiological stress to adjust functionally, structurally, and metabolically. After administration of jojoba oil, there was an increase in the expression of GLUT4 that may normalize myocardial glucose uptake and is a major mediator of myocardial glucose uptake in the heart. This result was in line with (Abel, 2004; Semeniuk et al., 2002; Belke et al., 2000).

GLUT4 deficiency increases cell death markers. GLUT4 has a critical role in hemodynamic stress responses (Wende et al., 2017). Neurons are high-energy-consuming cells. The brain glucose transporters are crucial for brain functions by supplying energy during neurotransmission ( Koepsell, 2020). Also, McNaya and Pearson-Learyb (2020) revealed the importance of GLUT4 as a transporter in the brain.

In the current study, with the administration of monosodium glutamate, the serum levels of troponin and CKMB were elevated. This is due to the inflammatory factors that cause direct injury to the myocardial cells and affect cardiac microcirculation, myocardial calcium ion transport, myocardial apoptosis, myocardial mitochondrial function, cardiac adrenergic receptors, thus leading to cardiac dysfunction. This dysfunction is manifested by increased cardiac enzymes and necrosis markers in the myocardium (Fei Yang et al., 2019).

The current study showed an increase in FFA with the administration of monosodium glutamate, together with downregulation of GLUT4 and an increase in oxidative stress and apoptosis. Seiva et al. (2012) were in line with these results, as the increasing cardiac FFA metabolism led to downregulation of GLUT4 mRNA as GLUT4 expression is exposed to endocrine and metabolic regulation; thus, fatty acids can modulate GLUT4 gene expression in the heart.

Normally, cardiac ATP is produced primarily by fatty acid oxidation (FAO), with a minor contribution from glucose metabolism. On the other hand, FAO may be decreased in response to stress, resulting in higher glucose use (Wende et al., 2017).

The heart switches from fatty acids to glucose as an energy substrate during injury. This switch increases lipid uptake and storage in the heart, resulting in lipotoxicity 
(Chanda et al., 2016). The level of circulating FFAs determines FFA uptake in the heart. Once absorbed, the FFA's metabolism is regulated at the transcriptional level (Stanley et al., 2005) that reflects the role of the nuclear factor. Increased FFA stimulates microglia and astrocytes to secrete cytokines (IL-1, TNF- $\alpha$ ) that have direct and toxic effects on the brain (Dalvi et al., 2017).

Hong et al. (2014) and Niu et al. (2013) showed that lipid metabolism disorders that enhance the inflammatory and oxidative reactions lead to neuronal apoptosis. These results were in line with the studies done by Weichun (2018), Yang et al. (2017), and Mi et al. (2012).

We found a decrease with GABA by administration of MSG. This agreed with Hashem et al. (2012), who reported that the neurotoxic effect of MSG leads to degenerative changes in neurons and cerebellar cortex of rats.

Neurotransmitters contribute to the formation of neural networks and regulate a variety of cellular and synaptic processes. Glutamate and gamma-aminobutyric acid (GABA), which are excitatory and inhibitory neurotransmitters, respectively, mediate excitatory and inhibitory neurotransmission. Additionally, glutamate and GABA are involved in neurologic illnesses such as cerebral ischemia. Excitotoxicity caused by glutamate has been a characteristic mechanism in the pathophysiology of cerebral ischemia injury for over three decades.

Excitotoxicity occurs due to excessive glutamate release, which activates postsynaptic glutamate receptors, triggering a downstream cascade that eventually results in neuronal dysfunction and degeneration. Following ischemia, decreased GABA receptor response prevents these inhibitory effectors from attenuating excitotoxicity, thus enabling the excitotoxic insult (Mayor and Tymianski, 2018).Also, Alicia Estacio-Gómez et al. (2020) stated that neurotransmitters regulated by transcription factors directly act positively, repressors of neurotransmitter fate (uniquely depleted transcription factors) also dynamic changes in expression pattern transcription factor directly promotes or represses the neurotransmitter fate.

In the current study, histopathological results revealed necrosis in cardiac muscles with apparent inflammatory infiltration, hemorrhage and vaculation in MSG-treated rats compared with control one, which improved by administering jojoba oil. These results go online with (Mirzakhani et al., 2020) and (Ogbuagu et al., 2019), who documented similar results. Also, histopathological results of the cerebral cortex of the brain tissue showed loss of the normal structure with many vacuolations and neuronal cell swelling and rounding with a pyknotic nucleus. They proliferated vascular spaces in MSG-treated rats compared with control one, which improved by administration of jojoba oil. These results agreed with (Abdou et al., 2020) and (Hamza et al., 2019).

\section{Conclusion}

The current data shows that food additives, particularly monosodium glutamate, cause brain and heart injury in rats, which is significantly improved by jojoba oil administration. This occurs by regulating inflammatory and metabolic status, as GLUT4 expression regulates metabolic processes and participates in the cardiac response to stress. Additionally, NF-kB is required for the regulation of stress and inflammatory gene expression.

\section{Conflict of interest}

The authors declare that there is no conflict of interest.

Ethics approval: Throughout the experiment, animals were handled humanely following the Benha Faculty of Medicine\& protocol for treating experimental animals.

Acknowledgements_molecular biology and biotechnology unit and pathology department. 


\section{REFERENCES}

Abdel-Mageed WM, Bayoumi SALH, Salama AAR, Salem-Bekhit MM, Abd-Alrahman SH, Sayed HM (2014): Antioxidant lipoxygenase inhibitors from the leaf extracts of Simmondsia chinensis. Asian Pacific Journal of Tropical Medicine; 7: S521S526.

Abdou H M, Hassan EH and Aly R G (2020): Monosodium glutamate (MSG): promoter of neurotoxicity, testicular impairment, inflammation and apoptosis in male rats. Swedish Journal of Scientific Research; 1(2): 78 - 90.

Abel ED (2010): Lipotoxicity in the heart. Biochim Biophys Acta; 1801:311-319.

Abudunaibi Maimaitiaili, Junhong Li, Aili Aibibula, and Mulati Abudureheman (2018): Inhibition of nuclear factor kappa B pathway protects myocardial ischemia/reperfusion injury in rats under treatment with abnormal savda munziq. American Journal of Translational Research ; 10 (1): 77-85.

Aerni-Flessner L, Abi-Jaoude M, Koenig A, Payne M and Hruz PW (2012): GLUT4, GLUT1, and GLUT8 are the dominant GLUT transcripts expressed in the murine left ventricle. Cardiovascular Diabetology; 11: 63.

Alalwani AD (2014): Monosodium glutamate induced testicular lesions in rats (histological study). Middle East Fertility Soceity Journal; 19:274-280.

Albensi B. C. and Mattson M. P. (2000): Evidence for the involvement of TNF and NFkappaB in hippocampal synaptic plasticity. Synapse; 35: 151-159.

Alicia Estacio-Gómez,Amira Hassan,Emma Walmsley,Lily Wong Le,Tony D. Southall (2020): Dynamic neurotransmitter specific transcription factor expression profiles during Drosophila development. Biology Open; 9 (5): bio052928.

Ashrafi Ghazaleh, Wu Zhuhao, Farrell Ryan J. and Ryan Timothy A. (2017): GLUT4 Mobilization Supports Energetic Demands of Active Synapses Neuron. Neuron; 93: 606-615.

Badr AN, Shehata MG, Abdel-Razek AG (2017): Antioxidant activities and potential impacts to reduce aflatoxins utilizing jojoba and jatropha oils and extracts. International Journal of Pharmacology; 13:1103-1114.

Bancroft J D, Gamble M (2008): Theory and Practice of Histology Techniques, 6th edition. Churchill Livingstone Elsevier, Philadelphia. 83 - 134.

Banerjee A, Das D, Paul R et al. (2020): Altered composition of high-lipid diet may generate reactive oxygen species by disturbing the balance of antioxidant and free radicals. Journal of Basic and Clinical Physiology and Pharmacology; 31: 1520.

Belke DD, Larsen TS, Gibbs EM, Severson DL (2000): Altered metabolism causes cardiac dysfunction in perfused hearts from diabetic $(\mathrm{db} / \mathrm{db})$ mice. American Journal of Physiology - Endocrinology and Metabolism; 279: E1104-E1113.

Bhattacharya T, Bhakta A and Ghosh S.K. (2011): Long term effect of monosodium glutamate in liver of albino mice after neo-natal exposure. Nepal Medical College Journal; 13: 11-16.

Blaschke F., Takata Y., Caglayan E., Law R. E. and HsuehW. A. (2006): Obesity, peroxisome proliferator-activated receptor, and atherosclerosis in type 2 diabetes. Arterioscler Thromb. Vascular. Biology; 26: 28-40.

Blaylock R (2007): "Food Additives: What You Eat Can Kill You." The Blaylock Wellness Report 4.

Chanda D., Luiken JJ, Glatz JF (2016): Signaling pathways involved in cardiac energy metabolism, Federation of European Biochemical Societies; 590(15):2364-2374. 
Dalvi PS, Chalmers JA, Luo V, Han DY, Wellhauser L, Liu Y, et al. (2017): High fat induces acute and chronic inflammation in the hypothalamus: effect of high-fat diet, palmitate and TNF-alpha on appetite-regulating NPY neurons. International Journal of Obesity; i41 (1):149-58.

El-Mallah MH, El-Shami SM (2009): Investigation of liquid wax components of Egyptian jojoba seeds. Journal of Oleo Science; 58:543-548.

Engelmann C., Weih F., and Haenold, R. (2014): Role of nuclear factor kappa B in central nervous system regeneration. Neural Regeneration Research; 9: 707-711.

Fei Yang, Li Na Zhao, Yi Sun, and Zhuang Chen (2019): levosimendan as a new force in the treatment of sepsis-induced cardiomyopathy: mechanism and clinical application . Journal of International Medical Research; 47(5): 1817-1828.

Haeggström JZ, Funk CD (2011): Lipoxygenase and leukotriene pathways: biochemistry, biology, and roles in disease. Chemical Reviews;111(10):5866-9588.

Hamza RZ, Al-Salmi FA, El-Shenawy NS (2019): Evaluation of the effects of the green nanoparticles zinc oxide on monosodium glutamate-induced toxicity in the brain of rats. Biochemistry, Biophysics and Molecular Biology; 7: e7460.

Hamzaa R Z and Diabb A A (2020): Testicular protective and antioxidant effects of selenium nanoparticles on Monosodium glutamate-induced testicular structure alterations in male mice. Toxicology Reports; 7:254-260.

Hashem HE, El-Din Safwat MD, Algaidi S (2012): The effect of monosodium glutamate on the cerebellar cortex of male albino rats and the protective role of vitamin $\mathrm{C}$ (histological and immunohistochemical study). Journal of Molecular Histology; 43(2):179-186.

Hayden M. S. and Ghosh S. (2012): NF-kB, the first quarter-century: remarkable progress and outstanding questions, Genes Develoment.; 26(3): 203-234.

Hazzaa S M, El-Roghy E S, Abd Eldaim M A, Elgarawany G E (2020): Monosodium glutamate induces cardiac toxicity via oxidative stress, fibrosis, and P53 proapoptotic protein expression in rats. Environmental Science and Pollution Research; 27: 20014-20024.

Helal EG, Barayan AW, Abdelaziz MA, El-Shenawe NS (2019): Adverse effects of monosodium glutamate, sodium benzoate and chlorophyllins on some physiological parameters in male Albino rats. Egyptian Journal of Hospital Medicine; $1 ;$ 74(8):1857-1864.

Henning SL, Wambolt RB, Schonekess BO, Lopaschuk GD, Allard MF (1996): Contribution of glycogen to aerobic myocardial glucose utilization. Circulation; 93(8):1549-1555.

Hong D, Bai YP, Gao HC, Wang X, Li LF, Zhang GG, et al. (2014): Ox-LDL induces endothelial cell apoptosis via the LOX-1-dependent endoplasmic reticulum stress pathway. Atherosclerosis; 235(2):310-317.

Jardim T. V. et al (2019): Cardiometabolic disease costs associated with suboptimal diet in the United State: a cost analysis based on microsimulation model. PLoS Medcine.; 16: e1002981.

Kadonaga J. T. (2004): Regulation of RNA polymerase II transcription by sequencespecific DNA binding factors. Cell; 116: 247-257.

Koepsell Hermann (2020): Glucose transporters in brain in health and disease, Archiv European Journal of Physiology; 472:1299-1343.

Lamas O., Moreno-Aliaga M. J., Martinez J. A., and Marti A. (2003): NF-kappa B-binding activity in an animal diet-induced overweightness model and the impact of subsequent energy restriction. Biochemical and Biophysical Research Communications; 311: 533-539. 
Lee T. I. and Young R. A. (2013): Transcriptional regulation and its misregulation in disease. Cell; 152: 1237-1251.

Liu H., Ma Y., Pagliari L J., Perlman H., Yu C., Lin A., et al. (2004): TNF-alpha-induced apoptosis of macrophages following inhibition of NF-kappa B: a central role for disruption of mitochondria. Journal of Immunology; 172: 1907-1915.

Manoharan S, Vishnupriya V, Gayathri R (2016): Phytochemical analysis and in vitro antioxidant activity of jojoba oil. Journal of Pharmaceutical Sciences; 8:512-516.

Mattson M. P., Culmsee, C., Yu, Z., and Camandola, S. (2000). Roles of nuclear factor kappaB in neuronal survival and plasticity. Journal of Neurochemistry; i. 74, 443456.

Mauro C., Leow S. C., Anso E., Rocha S., Thotakura A. K., Tornatore L., et al. (2011): NF-kappaB controls energy homeostasis and metabolic adaptation by upregulating mitochondrial respiration. Natural Cell Biology; 13: 1272-1279.

Mayor D. and Tymianski M. (2018): Neurotransmitters in the mediation of cerebral ischemic injury. Neuropharmacology; 15: 134(Pt B):178-188.

McNaya Ewan C., Pearson-Learyb Jiah (2020): GluT4: A central player in hippocampal memory and brain insulin resistance. Experimental Neurology; 323: 113076.

Mi Y, Ji-hua C, Guang-yu Z, Li-na Y, Ming-yuan Z, Min-yu H. Effect of hyperlipidemia on brain lipid in rats. Chinese Journal of Integrative Medicine; 22(19):6-11.

Mirzakhani N, Farshid AA, Tamaddonfard E, Tehrani A, Imani M (2020): Comparison of the effects of hydroalcoholic extract of Capparis spinosa fruit, quercetin and vitamin $\mathrm{E}$ on monosodium glutamate- induced toxicity in rats. Veterinary Research Forum; 11(2):127-134.

Mohamed IK (2012): The effects of oral dosage of monosodium glutamate applied for short- and long-terms on the histology and ultrastructure of testes of the adult rats. Journal of Animal Veterinary advances; 11(1): 124- 133.

Moldes AB, Vecino X and Cruz JM (2017): Nutraceuticals and food additives. In Current Developments in Biotechnology and Bioengineering; 1: 143-164.

Moretti M., Bennett J., Tornatore L., Thotakura A. K., and Franzoso G. (2012): Cancer: NF-kappaB regulates energy metabolism. International Journal of Biochemistry \& Cell Biology; 44: 2238-2243.

Nassar MH, Ibrahim IA, Sobhy HM, Saleh SY, Elbeltagy MA (2017): Effect of jojoba oil and extra virgin olive oil on genetic expressions and DNA damage in induced $\mathrm{CCl} 4$ toxicity in rats Egypt. Journal of Chemistry and Environmental Health; 3:93-109.

Niu N, Sun SZ, Han B, Wang Y. (2013): Relationship of ox-LDL/LOX-1 and vascular endothelial dysfunction of diet-induced obese immature rats and nicotinic acid's intervention outcomes. Zhonghua Yi Xue Za Zhi.; 93 (42): 3388-3393.

Ogbuagu E O, Airaodion A I, \& Ogbuagu U (2019): Histopathological Evaluation of Organs of Male Wistar Rats Fed with Monosodium Glutamate Treateddiet. International Research Journal of Gastroenterology and Hepatology; 2(2), $1-13$.

Onyema O O, Alisi CS, Ihetuge AP (2012): Monosodium glutamate induces oxidative stress and affects glucose metabolism in the kidney of rats. International Journal of Biochemistry Research \& Review; 2(1): 1-11.

Pateras I., Giaginis C., Tsigris C., Patsouris E. and Teocharis S. (2014): NF-kappaB signaling at the crossroads of infammation and atherogenesis: Searching for new therapeutic links. Emerging Therapeutic Targets; 18: 1089-1101.

Pereira RO, Wende AR, Olsen C, Soto J, Rawlings T, Zhu Y, Riehle C, Abel ED. (2014): GLUT1 deficiency in cardiomyocytes does not accelerate the transition from 
compensated hypertrophy to heart failure. Journal of Molecular and Cellular Cardiolog; 72:95-103.

Phillips SJ, Comus PW (2000) In: Phillips, S.J., Comus, P.W. (Eds.), A natural history of the Sonoran Desert. University of California Press, Berkeley and Los Angeles,CA, 256-257.

Rosa SG, Chagas PM, Pesarico AP, Nogueira CW (2018): Monosodium glutamate induced nociception and oxidative stress dependent on time of administration, age of rats and susceptibility of spinal cord and brain regions. Toxicology and Applied Pharmacology; Jul 15; 351: 64-73.

Sánchez M, Avhad MR, Marchetti JM, Martínez M, Aracil J (2016): Jojoba oil: a state-ofthe-art review and future prospects Energy Conversion and Management; 129:293-304.

Seiva FR, Chuffa LGA, Braga CP, Amorim JPA, Fernandes AAH (2012): Quercetin ameliorates glucose and lipid metabolism and improves antioxidant status in postnatally monosodium glutamate-induced metabolic alterations. Food and Chemical Toxicology; 50:3556-3561.

Semeniuk LM, Kryski AJ, Severson DL (2002): Echocardiographic assessment of cardiac function in diabetic $\mathrm{db} / \mathrm{db}$ and transgenic $\mathrm{db} / \mathrm{db}$-hGL hGLUT4 mice. American Journal of Physiology-Heart and Circulatory Physiology; 283:H976-H982.

Singh K and Ahluwalia P (2012): Effect of monosodium glutamate on lipid peroxidation and certain antioxidant enzymes in cardiac tissue of alcoholic adult male mice. Journal of Cardiovascular Disease Research; 3: 12-18.

Stanley WC, Recchia FA, Lopaschuk GD. (2005): Myocardial substrate metabolism in the normal and failing heart. Physiological Reviews; 85(3):1093-1129.

Szablewski Leszek (2017): Glucose transporters in healthy heart and in cardiac disease. International Journal of Cardiology; 230:70-75.

Tawfik M S, Al-Badr N (2012): Adverse effects of monosodium glutamate on liver and kidney functions in adult rats and potential protective effect of vitamins $\mathrm{C}$ and $\mathrm{E}$. Food and Nutrition Sciences; 3: 651-659.

Umukoro S, Oluwole G, Olamijowon H, Omogbiya A, Eduviere A (2015): Effect of monosodium glutamate on Behavioral phenotypes, biomarkers of oxidative stress in brain tissues and liver enzymes in mice. Biomedical Life Science; 5(5):339349.

Vaquerizas J. M., Kummerfeld S. K., Teichmann S. A. and Luscombe, N. M. (2009): A census of human transcription factors: function, expression and evolution Nature Reviews Genetics; 10: 252-263.

Vega Rick B., Kelly Daniel P. (2017): Cardiac nuclear receptors: architects of mitochondrial structure and function. Journal of Clinical Investigation; 127(4):1155-1164.

Walker R, Lupien JR (2000): The safety evaluation of monosodium glutamate. Journal of Nutrition1; 130(4): 1049S-52S.

Weichun Yang, Ziyi Shen, Sixian Wen, Wei Wang, and Minyu Hu (2018): Mechanisms of multiple neurotransmitters in the effects of Lycopene on brain injury induced by Hyperlipidemia. Lipids in Health and Disease; 17, Article number: 13.

Wende AR, Kim J, Holland WL, Wayment BE, O’Neill BT, Tuinei J, Brahma MK, Pepin ME, McCrory MA, Luptak I, Halade GV, Litwin SE, Abel ED. (2017): Glucose transporter 4-deficient hearts develop maladaptive hypertrophy in response to physiological or pathological stresses. American Journal of PhysiologyHeart and Circulatory Physiology; 313: H1098 -H1108. 
Yang W, Shi H, Zhang J, Shen Z, Zhou G, Hu M. (2017): Effects of the duration of hyperlipidemia on cerebral lipids, vessels and neurons in rats. Lipids in Health and Disease; 16(1):26-34.

Zanfirescu A, Ungurianu A, Tsatsakis AM, et al. (2019): A review of the alleged health hazards of monosodium glutamate. Comprehensive Reviews in Food Science and Food Safety; 18: 1111-1134.

Zhong Z., Umemura A., Sanchez-Lopez E., Liang S., Shalapour S., and Wong J., et al. (2016): NF-kappaB restricts inflammasome activation via elimination of damaged mitochondria. Cell; 164:896-910. 